\title{
THE PROPOSITION OF THE METHOD IMPROVING THE IDENTIFY THE ROOT OF PROBLEM
}

\author{
Dominika SIWIEC ${ }^{1}$, Andrzej PACANA ${ }^{2 *}$ \\ ${ }^{1}$ Rzeszow University of Technology, Faculty of Mechanical Engineering and Aeronautics, Rzeszow, Poland; \\ d.siwiec@prz.edu.pl, ORCID: 0000-0002-6663-6621 \\ ${ }^{2}$ Rzeszow University of Technology, Faculty of Mechanical Engineering and Aeronautics, Rzeszow, Poland; \\ app@prz.edu.pl, ORCID: 0000-0003-1121-6352 \\ * Correspondence author
}

Purpose: The aim of the work was to propose the integrated decision method with quality techniques to precision identify the root of the problem.

Design/methodology/approach: The proposed method was integrated methods as the Ishikawa diagram, 5Why method and AHP method. An idea of the proposed method was improving the process of identifying the problem by using a new mixed-method, ie. after Ishikawa diagram the methods 5Why and AHP.

Findings: It was demonstrated, that it is purposeful using the proposed mixed method (ie. qualitative and quantitative) to expand the horizon of identifying the root cause.

Research limitations/implications: The limitation is the subjectivism of the entity using the method, which is revealed during assessing the causes of a problem. Therefore, future works will be based on the minimalization of subjectivism by using the fuzzy Saaty scale.

Practical implications: The proposed method is a new approach to analyse different types of problems and support the process of solve decision problems. Therefore, this method can be practice in service and production enterprises to identify the root of product incompatibility.

Social implications: Using the method allows improving the process of making the decision about causes of the problem, and limits the possibility of wrong decision about the source of the problem.

Originality/value: The proposed method was used a new proposal of mixed-method, ie. it was used integrated the Ishikawa diagram, 5Why method and AHP method. The presented method is some kind of a new approach to identify the root of the problem.

Keywords: quality management, mechanical engineering, incompatibility of product, improving the quality, mixed method.

Category of the paper: research paper, technical paper. 


\section{Introduction}

Analysis of incompatibility of product which are made with using the quality management instruments allows effective quality management of product and also making adequate improving actions (Liu et al., 2017; Pacana, Czerwińska and Siwiec, 2018). As part of using quality management instruments, it is possible to analyse the causes of occurrence this incompatibility (Pacana et al., 2019; Siwiec, Bednarowa and Pacana, 2020; Siwiec et al., 2019). That it would be possible, it is necessary to use the appropriately selected instruments, where a primary is Ishikawa diagram (Liu et al., 2017; Pacana, Siwiec and Bednarowa, 2019). The Ishikawa diagram allows identify the potential causes of a problem and because it is creating in a graphical way (in a form so-called fish), the analysis of the problem is easier (Luca, 2016; Silva et al., 2019). Analysis of the problem by the Ishikawa diagram relies on to analyse the relationships of cause and effect (Meyer, 2003), where it is possible to identify the potential causes and main causes of a problem. Therefore, in the aim of identifying the root of the problem, the diagram often occurs with using the 5Why method (Pacana, Siwiec and Bednarowa, 2019). The mentioned method $5 \mathrm{Why}$ is an instrument to identify the root of causes (Braglia, Frosolini and Gallo, 2017). This method involves asking "Why?" into a moment of identifying the root of the problem, which generate the reduce or eliminate the occurs the problem in the future (Lindhard, 2014).

The literature review is pointed out that the 5 Why method, which is a qualitative method and has character of decision method (making a decision about root cause), was not extend as part of the effective analysis (at the same time qualitative and quantitative) (Kawalec, 2014) in order to precise identify the root cause. In turn, according to literature sources, using the mixed method to solve the problem (ie. integrated qualitative and quantitative method to solve one problem) allows eliminating the restrictions of individual methods, and also the precision of results at a given stage of the analysis (Kawalec, 2014; Molina-Azorin, 2016; Shorten and Smith, 2017). It was concluded that the 5Why method is still of interest (Braglia, Frosolini and Gallo, 2017; Lindhard, 2014; Pacana, Siwiec and Bednarowa, 2019), but the precision of pointed the root of cause as part of this method not was improving, which is a gap in making effective analyses of quality problems, for example as part of traditional sequence of Ishikawa diagram and 5 Why method.

Therefore, the aim of the work was to propose the method, which in effective and precise way, will allow on identify the root of the problem. This method was a sequence of the Ishikawa diagram and the 5Why method which was integrated with AHP method (Analytic Hierarchy Process), which is a multi-criteria hierarchical method, effective in criteria analysis, among others about the qualitative character) (Horvathova, Copikova and Mokra, 2019; Iwanejko and Rybicki, 2008). As part of the testing of the proposed method, the porosity cluster on the mechanical sealer was analyzed, which was identified by the fluorescent method (FPI) in service and production enterprise localized on Podkarpacie. 


\section{Subject of the study}

The subject of the study was mechanical sealer, having application in fluid retention in technologies, among others flight (Uszczelnienie mechaniczne). The mechanical sealer was from 410 alloy, which is not being martensitic stainless steel that has been hardened (Stone, Alexandrov and Penso, 2018). The choice of mechanical sealer to analyze it was resulted from relatively often identify on it incompatibilities, ie. porosity cluster. Also, the choice resulted from problematic analysis of the incompatibilities of casts, which results from differences in individual casting processes (Chokkalingam et al., 2017). At the same time, the root cause of the problem was not clearly identified. Additionally, the enterprise in which the problem occurred, it was sought to still develop, which is possible in the context of making effective actions having in aim the eliminate or minimalize the occur of incompatibility of problem. Therefore, it was considered that as part of testing the proposed method, it is possible to analyze of incompatibility porosity cluster on the mechanical sealer.

\section{Method}

Proposed method was integrated methods ie. Ishikawa diagram, 5Why method and multicriteria method of hierarchical analysis of decision problems (AHP). Idea of proposed method was improving the process of identify the incompatibility by sing mixed method (ie. qualitative and quantitative). In the proposed method, by the Ishikawa diagram, the potential causes of the problem were identified, which were pointed during the brainstorm among selected workers. From the potential causes, the main causes were selected. Next, the main causes were analyzed by 5 Why method in order to identify the indirect causes. In turn, in order to identify in a precise way the root of the problem, the 5Why method with the AHP method was integrated, as part it the analysed in a detailed way (numerical) all indirect causes for given root causes. Thanks for this, it was possible pointed in unequivocal (based on weight obtained) the root cause.

Application in proposed method the sequence of Ishikawa diagram and next the 5Why method resulted from proven effectiveness these methods in identifying the potential causes, main and root causes (Pacana et al., 2019). In turn, integrated the 5Why method with the AHP method, resulted from the qualitative character of the 5Why method (Molina-Azorin, 2016; Shorten and Smith, 2017) and so from limits in precisely pointed the root of the problem. Additionally, analyze of the problem by both methods (5Why and AHP) has a decision character (Saaty, 2007), ie. making decisions about the causes of the problem. In turn, the effectiveness of the decision process generates the quality of precision of pointed the root cause (Shin, Lee and Son, 2015). Also, the results of the integrated method (5Why and AHP) 
are results of mixed method, which, as indicated in literature sources, is more effective than the results of the 5Why method, which is only qualitative (Kawalec, 2014; Molina-Azorin, 2016; Shorten and Smith, 2017). Therefore, it was concluded that it is appropriate to integrate the 5Why method with the AHP method to achieve a precision (calculated) by identifying the root of the problem.

Proposed method was complex from five main steps. In order to test the proposed method, it was analyzed the problem with porosity cluster on the mechanical sealer, which was identified by FPI method in service-production enterprise localized in Podkarpacie.

\section{First step}

In the first step of the method, the aim was precised, which was to identify the root of the porosity cluster on the mechanical sealer.

\section{Second step}

In the second step, the Ishikawa diagram was created. The problem (porosity cluster) was pointed in the main part of the diagram. Next, the categories to analyse the problem were selected, which was mainly categories of Ishikawa (rule 5M+E), ie. man, method, machine, material, management and environment (Luca, 2016; Meyer, 2003; Pacana et al. 2019). Next, to each of the categories, the potential causes of the problem were noted, from which the main causes were selected (Ulewicz, 2003).

\section{Third step}

In the third step in the aim of identifying the root of the problem the analysis by the 5 Why method was made, which were next integrated with the AHP method. Therefore, to the problem of the porosity cluster, the main causes were pointed (identified as part of the Ishikawa diagram). Next, to the main causes the „Why?” question was asked in order to identify the indirect causes (Shin, Lee and Son, 2015). Analyse of the problem by the 5 Why method was ended at the moment in which all indirect causes were identified, which was resulted from the character of the proposed method where the root cause was identified in process of analyse by the AHP method.

\section{Fourth stage}

Next, in the fourth stage, with the aim of identifying the root of the problem, the causes were analyzed by the AHP method. This stage was divided into six steps.

\section{First step}

In the first step, the assessment of the main causes of the problem was made (ie. the weight - influence the cause of occurrence the problem). In this aim by the scale proposed by Saaty (creator of the AHP method), ie. 1-9, the entity using the method awards grades of main causes, where the grade 1 - the causes least important, 9 - absolutely the most important (Stoltmann 2016). 


\section{Second step}

In the second step, the assessment of indirect causes of the problem was made (ie. the weight was determined, it is the influence of indirect cause on occurrence the problem). The grades were granted by the entity using the method, by the Saaty scale (1-9).

\section{Third step}

In the third step, the main causes were compared in pairs, and next the indirect causes, which were identified for main causes, and were noted in the Saaty matrix. There is always a value of 1 on the diagonal, which means that the causes of the problem are equivalent. In turn, above the diagonal of the matrix is the value of the comparison of causes, and the reverse value of the comparison (Stoltmann, 2016).

\section{Fourth step}

In the fourth step, the weights of the main causes and indirect causes (which were identified for the main causes) were calculated, where the obtained the sum of main causes weights have to be equal 1 and also the sum of indirect causes for each of main cause have to be equal 1 , which proves the correctness of the calculations (Stoltmann, 2016).

\section{Fifth step}

In the fifth step, it was checked whether the results obtained did not violate the principle of constancy of preferences (1-3) (Horvathova et al., 2019; Stoltmann, 2016):

$$
\begin{aligned}
& \lambda_{\text {max }}=\frac{1}{w_{i}} \sum_{j=1}^{k} w_{i j} w_{j} \\
& C I=\frac{\lambda_{\max }-n}{r(n-1)} \\
& C R=\frac{C I}{r}
\end{aligned}
$$

where:

$\lambda \max -$ coherence factor,

$\mathrm{n}-$ number of causes (main or indirect),

$\mathrm{r}$ - average random index value for $\mathrm{n}$ according to Saaty.

Full compatibility of results is achieved when $\lambda \max =n, C I=0, C R=0$. However, the compatibility of results is acceptable for $\lambda$ max near $n$, for $\mathrm{CI}<0,1$ and $\mathrm{CR}<0,1$ (Stoltmann, 2016; Siwiec, Bednarowa and Pacana, 2020). If not obtained full or acceptable compatibility of results, which resulting from incoherent giving grades, it belongs repeat the process shown in the fourth step until to the moment achieve full or acceptable compatibility of results. 


\section{Sixth step}

In the sixth step, it is necessary to multiply the weights of main causes by the weights of its indirect causes, and next show the maximum weights of indirect causes which belong to the main cause, so the causes which in the greatest influence on occurrence the problem.

\section{Fifth stage}

The fifth stage, so the last stage of the proposed method concerns of indication the root of the problem. The root of the problem according to the proposed method, is the cause which among indirect causes identified in the fifth step has the greatest weight.

\section{Results}

As part of testing the proposed method, in the first stage precised the aim, which was to identify the root of porosity cluster on mechanical sealer. The incompatibility was identified during the fluorescent method in the service-production enterprise localized in the Podkarpacie. An example of an occurrence of the porosity cluster on the mechanical sealer is shown in Figure 1.

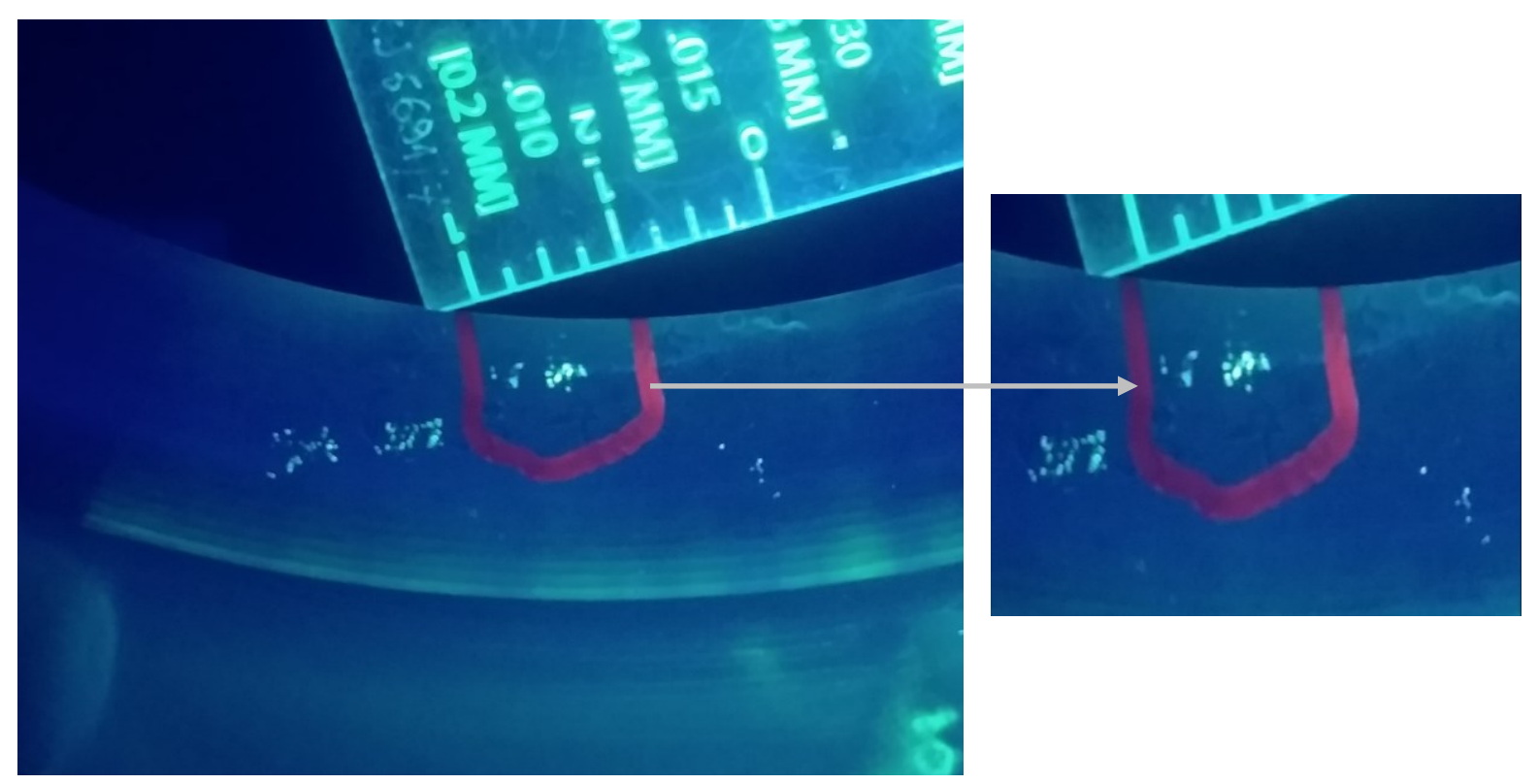

Figure 1. An example of the porosity cluster on the mechanical sealer.

Then, in the second stage, in order to identify the potential causes of the problem with the porosity cluster on the mechanical sealer, the Ishikawa diagram was created (Figure 2). Of the potential causes showing on the Ishikawa diagram, the main causes of porosity cluster were selected during the brainstorm, ie. bad mass quality, bad quality of form and impurities. 
In the third stage, the analysis of the problem with the porosity cluster by the 5 Why method was made (Figure 3). Using the 5 Why method, only the indirect causes of the problem were identified, without indicating the root cause, which was identified in the proposed technique using the AHP method. Therefore, in the fourth step by the AHP method, the main and indirect causes were analyzed. After giving an assessment to main and indirect causes in Saaty scale (1-9), there were compared in pairs (Table 1).

Table 1.

The results of the compared in pairs the main and indirect causes of porosity cluster

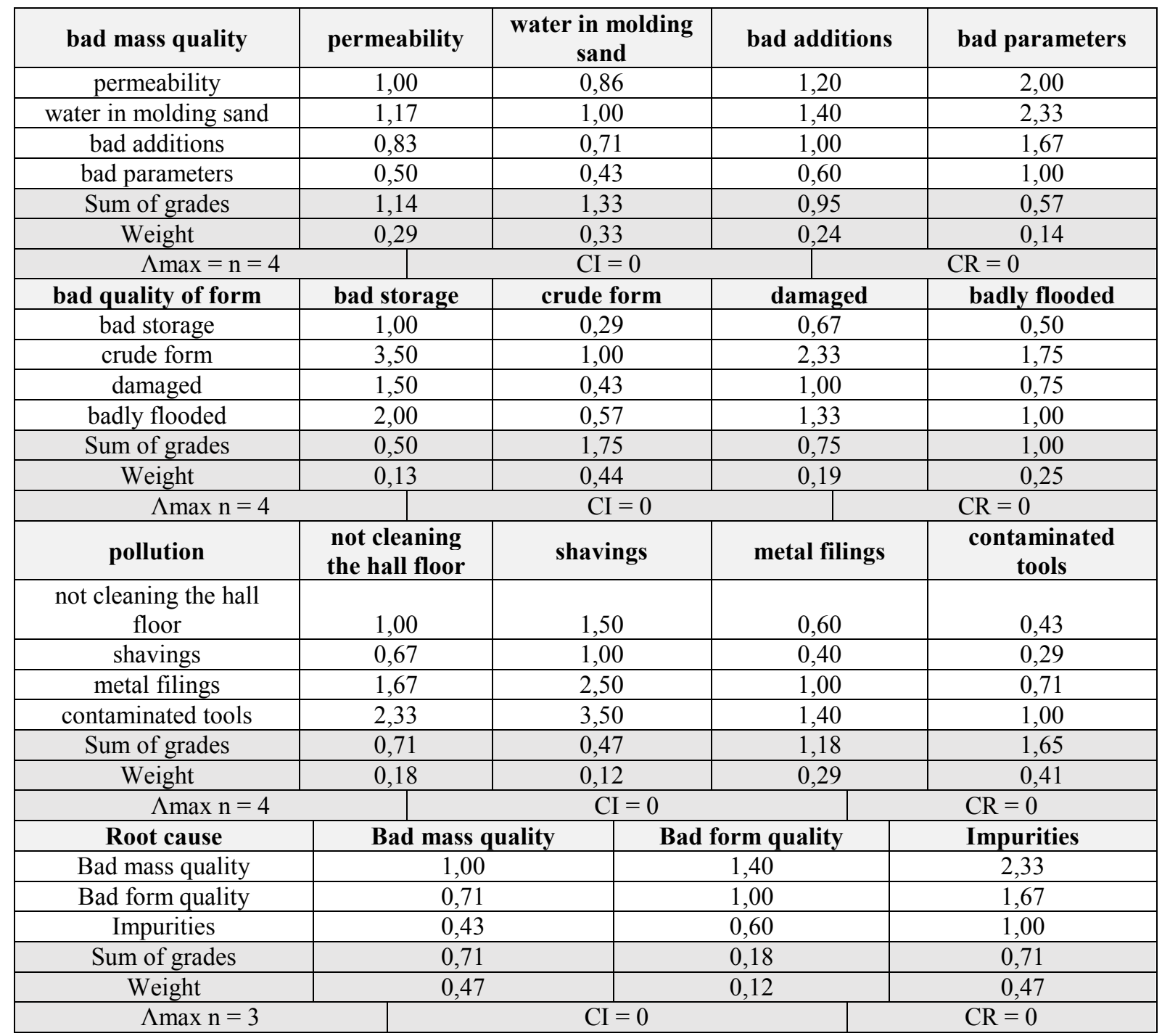

Then, the analysis of results was made, in aim to check the stability of preferences. The average random index according to Saaty, which was chosen was equal $r=0,58$, for the main causes, ie. $n=3$ and also $r=0,9$ for the indirect causes ie. $n=4$ (Stoltmann, 2016). It was shown full compliance of results (ie. $\lambda \max =n, C I=0, C R=0$ ), so it was possible to made further analysis of the problem. Therefore, the weights of the main causes (ie. bad mass quality, bad quality of form and impurities) by the weights of indirect causes were multiplied (Table 2). 
Table 2.

A set of weights of indirect causes and choice the root cause

\begin{tabular}{|c|c|c|c|}
\hline Cause & Weight & \multirow{2}{*}{ Ranking } & \multirow{2}{*}{$\begin{array}{c}\text { Maximum weight } \\
\text { Root cause } \\
\end{array}$} \\
\hline Bad mass quality & 0,47 & & \\
\hline Permeability & 0,13 & 2 & \multirow{5}{*}{ water in molding sand } \\
\hline water in molding sand & 0,16 & 1 & \\
\hline bad additions & 0,11 & 3 & \\
\hline bad parameters & 0,07 & 4 & \\
\hline bad quality of form & $\mathbf{0 , 3 3}$ & Ranking & \\
\hline bad storage & 0,04 & 4 & \\
\hline crude form & 0,15 & 1 & \\
\hline damaged & 0,06 & 3 & \\
\hline badly flooded & 0,08 & 2 & \\
\hline impurities & $\mathbf{0 , 2 0}$ & Ranking & \\
\hline not cleaning the hall floor & 0,04 & 3 & \\
\hline shavings & 0,02 & 4 & \\
\hline metal filings & 0,06 & 2 & \\
\hline contaminated tools & 0,08 & 1 & \\
\hline
\end{tabular}

The indirect causes, having the maximum weights, so the causes which in the greatest influenced on the occurrence the porosity cluster were: water in molding sand (weight 0,16 ), crude form (weight 0,15 ), contaminated tools (weight 0,08 ). According to the proposed method, the root cause of the porosity cluster was water in molding sand, having the maximum weight among indirect causes. The root of the problem (water in molding sand) belongs to the main cause ie. bad quality of form. The result of the integration of the 5Why method with the AHP method is shown in Figure 4.

\section{Discussion and summary}

The effective using the quality management instruments as part of the analysis of the incompatibility of products increases the likelihood of reducing or eliminating these incompatibilities. It is often making by the Ishikawa diagram and the 5 Why method. However, after the literature review, it was concluded that the precision of identifying the root causes as part of these techniques is not improved, what is a gap in making effective analyses of problems. The aim of the work was to propose the integrated decision method with quality techniques to precision identify the root of the problem. This method was sequence of the Ishikawa diagram and the 5 Why method which was combined with the AHP method. An idea of the proposed method was improving the process of identifying the problem by using the mixed method (ie. qualitative - Ishikawa diagram, 5Why method and quantitative - AHP method). In order to test the proposed method, it was analyzed the problem with porosity cluster on the mechanical sealer, which was identified by FPI method in service-production enterprise localized in Podkarpacie. By the Ishikawa diagram, the potential causes were identified, among which the 
main causes were selected, ie. bad mass quality, bad quality of form and impurities. Then, by the 5Why method, the indirect causes of problem were identified, but the root of cause was pointed by using the AHP method. After made the calculation it was shown that the causes which in the greatest influence on the occurrence the porosity cluster were: water in molding sand (weight 0,16 ), crude form (weight 0,15 ), contaminated tools (weight 0,08 ). The root cause of the porosity cluster was water in molding sand, having the maximum weight among indirect causes (ie. 0,16). It was shown that it is possible to using the Ishikawa diagram and integrated 5 Why method and AHP method in aim of better knowledge of the process and precise identify the root of problem. In proposed method the mixed method was used (qualitative and quantitative), ie. it was used integrated the Ishikawa diagram, 5Why method and AHP method. The proposed method is a new approach to analyse different types of problems and support the process of solve decision problems. Therefore, this method can be practice in service and production enterprises to identify the root of product incompatibility.

\section{References}

1. Braglia, M., Frosolini, M., Gallo, M. (2017). SMED enhanced with 5-Whys Analysis to improve set-upreduction programs: the SWAN approach. International Journal of Advanced Manufacturing Technology, 90, 5-8, pp. 1845-1855. doi: https://doi.org/ 10.1007/s00170-016-9477-4.

2. Chokkalingam, B., Raja, V., Anburaj, J., Immanual, R., Dhineshkumar M. (2017). Investigation of shrinkage defect in castings by quantitative Ishikawa diagram. Archives $O f$ Foundry Engineering, 17, 1, pp. 174-178.

3. Horvathova, P., Copikova, A., Mokra, K. (2019). Methodology proposal of the creation of competency models and competency model for the position of a sales manager in an industrial organisation using the AHP method and Saaty's method of determining weights. Economic Research-Ekonomska Istrazivanja, 32, 1, pp. 2594-2613. doi: 10.1080/ 1331677X.2019.1653780.

4. Iwanejko, R., Rybicki, S. (2008). Praktyczne aspekty stosowania metody heirarchicznego wyboru AHP $w$ zagadnieniach zaopatrzenia $w$ wodę. XX Jubileuszkowa-Krajowa, VIII międzynarodowa Konferencja Naukowo-Techniczna „Zaopatrzenie w wodę, jakość i ochrona wód", Polska.

5. Kawalec, P. (2014). Metody mieszane w kontekście procesu badawczego w naukoznawstwie. Zagadnienia Naukoznawstwa, 1, 199, pp. 1-22.

6. Lindhard, S. (2014). Applying the 5 WHYs to Identify Root Causes to Non-completions in On-Site Construction. In Lecture Notes in Production Engineering, Conference: 7th World 
Conference on Mass Customization, Personalization, and Co-Creation (MCPC), Denmark, pp. 51-61.

7. Liu, K., Wang, Y., Lin, L. et al. (2017). An Analysis of Impact Factors for Positioning Performance in WLAN Fingerprinting Systems Using Ishikawa Diagrams and a Simulation Platform. Mobile Information Systems, pp. 1-20. doi: 10.1155/2017/8294248.

8. Luca, L. (2016). A new model of Ishikawa diagram for quality assessment. IOP Conf. Series: Materials Science and Engineering, 161, pp. 1-6, doi:10.1088/1757899X/161/1/012099.

9. Meyer, V.R. (2003). Measurement uncertainty of liquid chromatographic analyses visualized by Ishikawa diagrams. Journal OfChromatographic Science, 41, 8, pp. 439-443. doi: 10.1093/chromsci/41.8.439.

10. Molina-Azorin, J.F. (2016). Mixed methods research: An opportunity to improve our studies and our research skills. European Journal of Management and Business Economics, 25, 2, pp. 37-38. doi: 10.1016/j.redeen.2016.05.001.

11. Pacana, A., Czerwińska, K., Siwiec, D. (2018). Narzędzia i wybrane metody zarzadzania jakościa. Teoria $i$ praktyka. Oficyna Częstochowa: Wydawnicza Stowarzyszenia Menedżerów Jakości i Produkcji.

12. Pacana, A., Siwiec, D., Bednarova, L. (2019). Analysis of the incompatibility of the product with fluorescent method. Metalurgija, 58, 3-4, pp. 337-340.

13. Pacana, A., Siwiec, D., Bednárová, L., Hajduová, Z. (2019). The selected methods of quality management used for the evaluation of label printing. Przemyst Chemiczny, 98, 1, pp. 110-112. doi: 10.15199/62.2019.1.17.

14. Pacana, A., Siwiec, D., Bednárowá, L., Hajduová, Z. (2019). Wybrane metody zarządzania jakością stosowane do oceny druku etykiet. Przemyst Chemiczny, 98, 1, pp. 110-112. doi: 10.15199/62.2019.1.17.

15. Saaty, T.L. (2007). Time dependent decision-making; dynamic priorities in the AHP/ANP: Generalizing from points to functions and from real to complex variables. Mathematical And Computer Modelling, 46, 7-8, pp. 860-891. doi: 10.1016/j.mcm.2007.03.028.

16. Shin, D.G., Lee, S.I., Son, K.S. (2015). Countermeasure for construction machinery produced using 5Why technique. International Journal of Engineering and Technology, 7, 4, pp. 1478-1486.

17. Shorten, A., Smith, J. (2017). Mixed methods research: expanding the evidence base. Evid Based Nurs, 20, 3, pp. 74-75. doi: http://dx.doi.org/10.1136/eb-2017-102699.

18. Silva, D., Viana, S., Ferreira, B. et al. (2019). Causes and Solution Strategies for Hanseniasis in Children: Ishikawa Diagram. Revista De Pesquisa-Cuidado E Fundamental Online, 11, 3, pp. 739-747. doi: 10.9789/2175-5361.2019.v11i3.739-747.

19. Siwiec, D., Bednárowá, L., Pacana, A., Zawada, M., Rusko, M. (2019). Wspomaganie decyzji w procesie doboru penetrantów fluorescencyjnych do przemysłowych badań nieniszczących. Przemyst Chemiczny, 98, 10, pp. 1594-1596. doi: 10.15199/62.2019.10.12. 
20. Siwiec, D., Bednárowá, L., Pacana, A. (2020). Metoda doboru penetrantów dla przemysłowych badań nieniszczących. Przemyst Chemiczny, 99, 5, pp. 771-773. doi: 10.15199/62.2020.5.18.

21. Stoltmann, A. (2016). Application of AHP Method for Comparing the Criteria Used in Locating Wind Farms. Acta Energetica, 3, 28, pp. 144-149. doi: 10.12736/issn.23003022.2016313 .

22. Stone, D.J., Alexandrov, B.T., Penso, J.A. (2018). Alloy Composition and Critical Temperatures in Type 410 Steel Welds. Welding Journal, 97, 10, pp. 286S-300S. doi: $10.29391 / 2018.97 .025$.

23. Ulewicz, R. (2003). Quality Control System in Production of the Castings from Spheroid Cast Iron. Metalurgija, 42, 1, pp. 61-63.

24. Uszczelnienie mechaniczne. Available online https://www.aesseal.com/pl/resources/ academy/czym-jest-uszczelnienie-mechaniczne, 28.04.2020.

25. Wykorzystanie komputerowego wspomagania w zakresie metody 5 Why $\mathrm{w}$ przemyśle. Available online http://www.ptzp.org.pl/files/konferencje/kzz/artyk_pdf_2011/116.pdf, 28.04.2020. 


\section{Appendix}

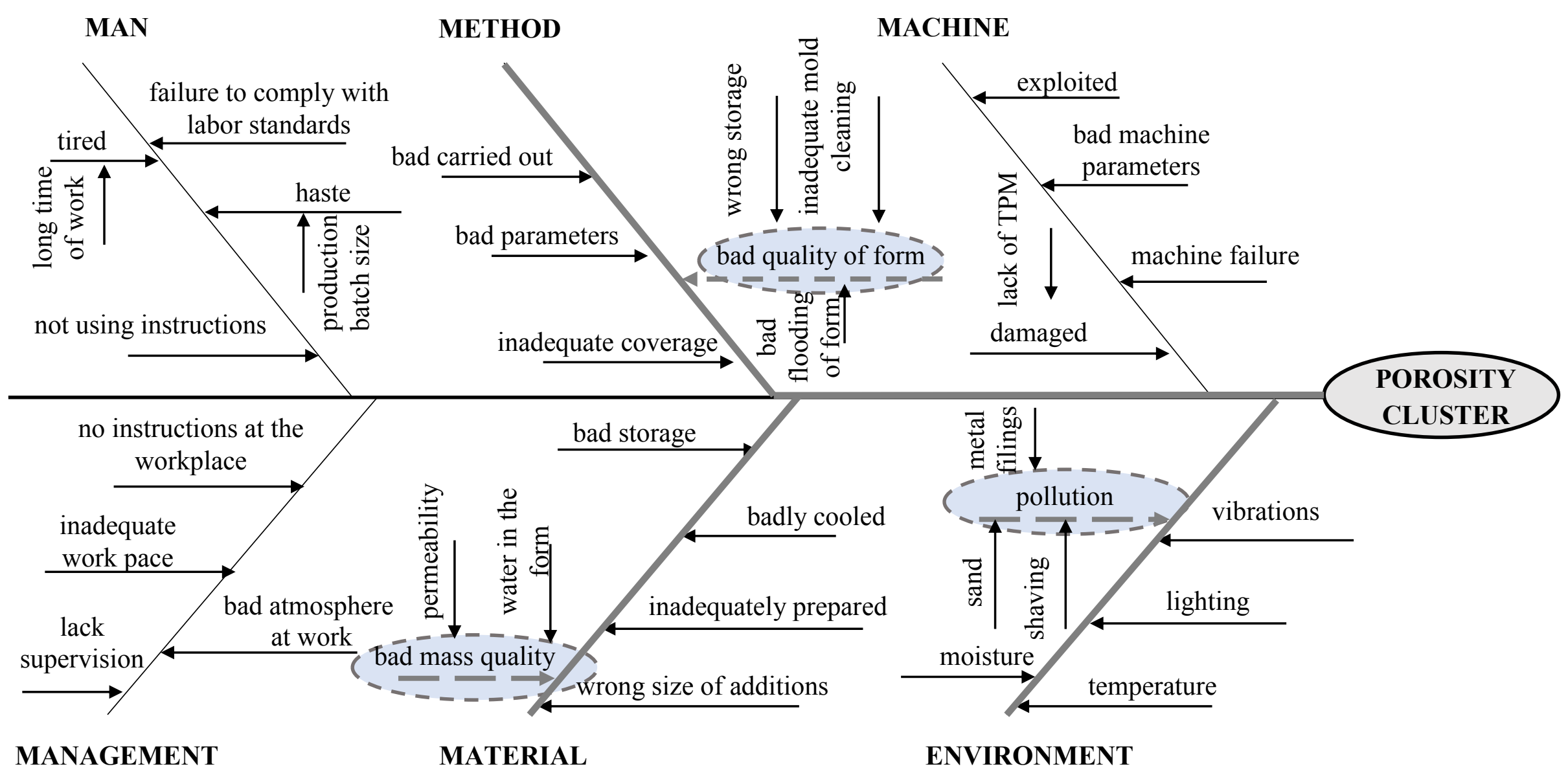

Figure 2. The Ishikawa diagram for the problem of porosity cluster. 


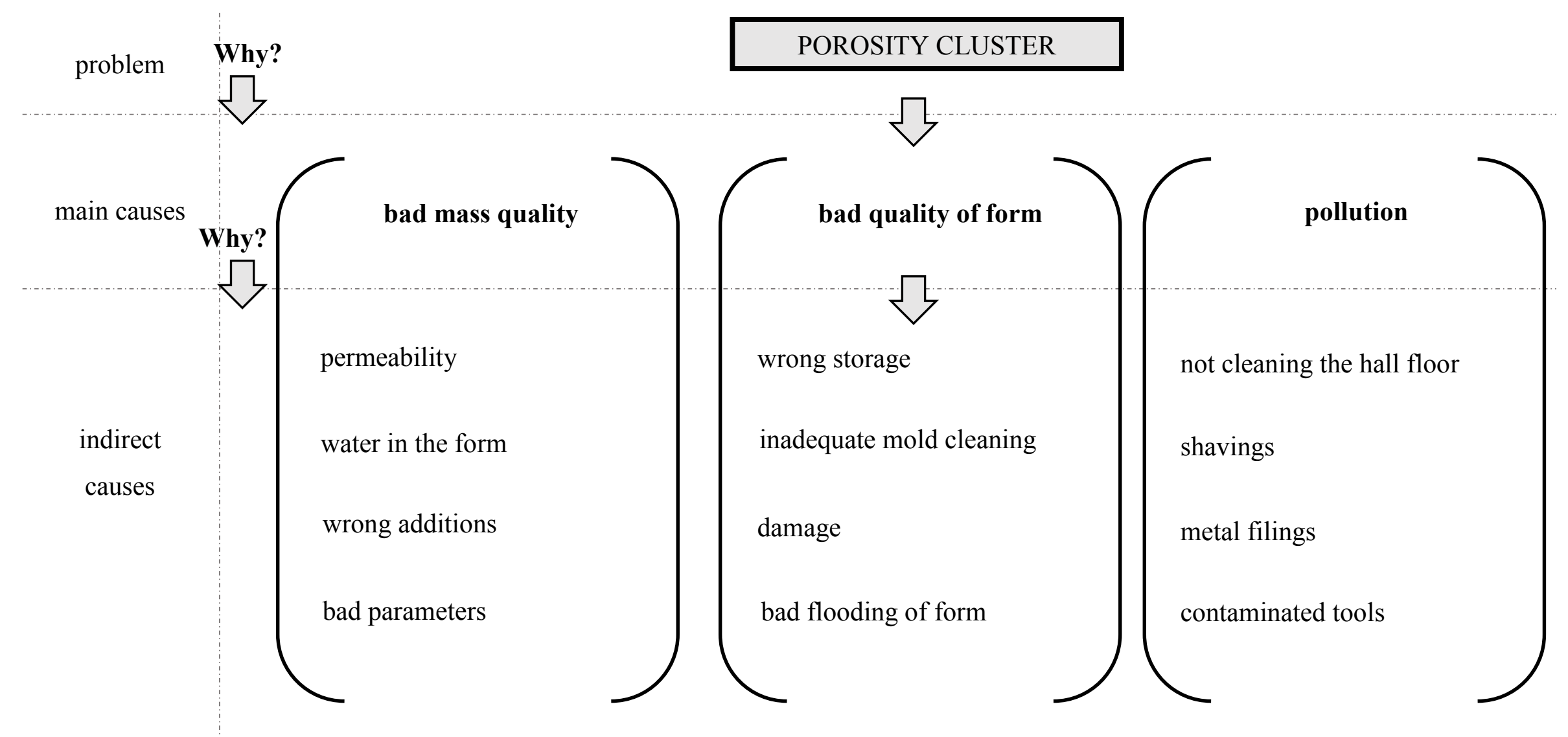

Figure 3. Using the 5 Why method to identify the indirect causes of the problem with porosity cluster. 


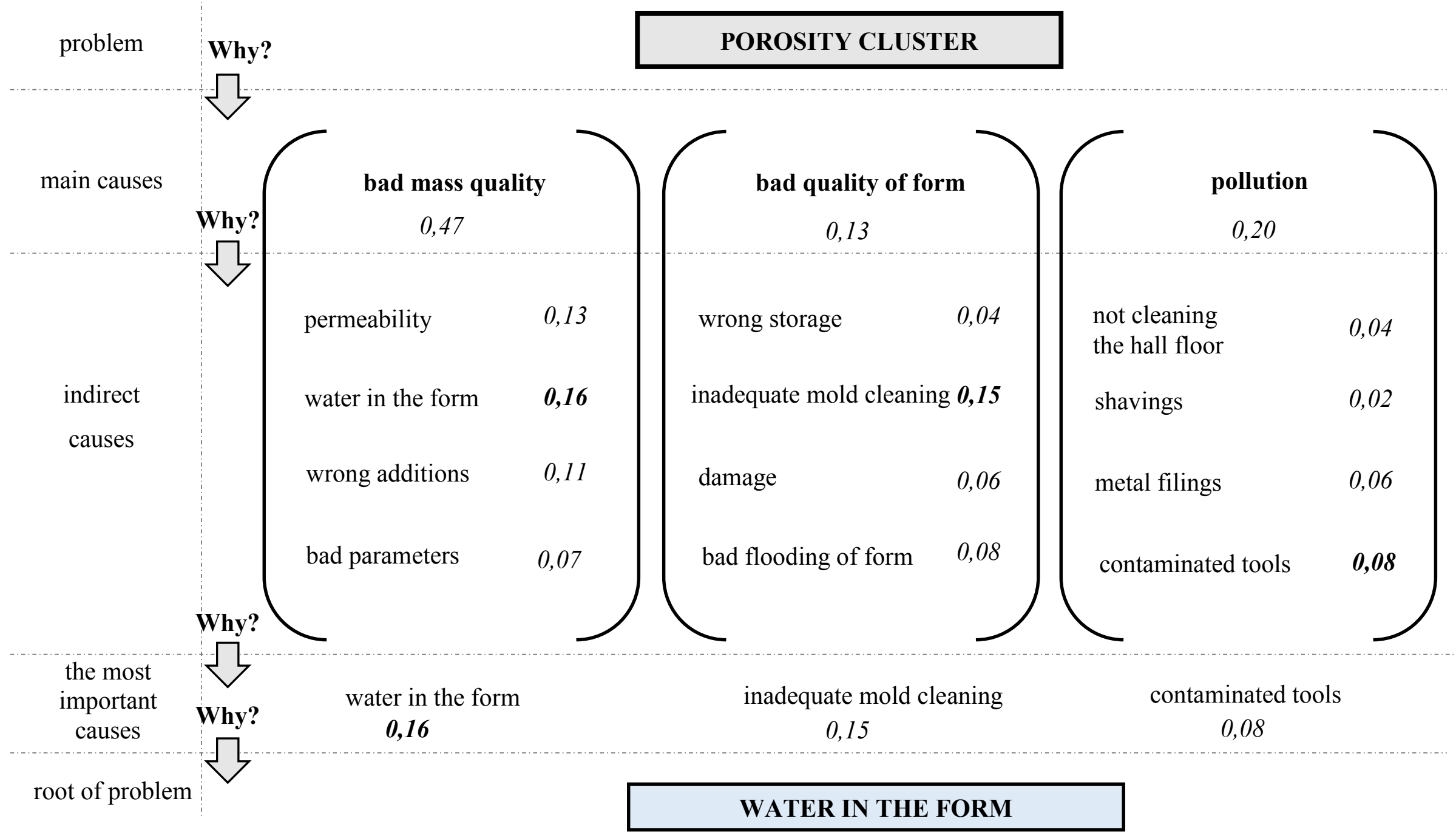

Figure 4. Results of integrated the 5Why method with the AHP method. 